\title{
The Role of Lazismu on Entrepreneurship Empowerment Program for the Poor
}

\author{
Sutrisno $^{1, *}$, Razali Haron ${ }^{2}$, Rozikan $^{3}$

\begin{abstract}
${ }^{1}$ Department Islamic Economics Faculty of Islamic Studies, Universitas Muhammadiyah Yogyakarta Indonesia ${ }^{2}$ IIUM institute of Islamic Banking and Finance (IIBBF) International Islamic University of Malaysia

${ }^{3}$ Department Islamic Economics Faculty of Islamic Studies, Universitas Muhammadiyah Yogyakarta Indonesia
\end{abstract} \\ *Corresponding author. Email: sutrysno@umy.ac.id
}

\begin{abstract}
Zakat institutions play a strategic role in the management of zakat funds and other social funds in order to carry out the law's mandate and alleviate poverty through various programs. Meanwhile, zakat institutions are responsible for the majority of poverty alleviation through consumptive programs. Based on the results of the Lazismu National Zakat Institute's management, it has obtained the largest zakat fund acquisition achievement nationally in 2020. This study aims to explore in depth how zakat programs are created, managed, and implemented for economic empowerment of the poor in Lazismu by interviewing, which has been successful in creating and implementing economic empowerment programs for zakat recipients throughout Indonesia. This study took a qualitative approach, with data collected through interviews. The results Lazismu's role through the poor community empowerment program is carried out in several stages, starting from the preparation of the strategic plan before the program is implemented, determining the type of program, implementation, evaluation and mentoring. The program of Lazismu is in the form of rising farmers, MSMEs, livestock, capital assistance for Islamic microfinance institutions in accordance with the theory of raising the spirit of entrepreneurship and smart goals. Overall economic empowerment program carried out by Lazismu, in general, it went well and smoothly according to the planned target. In addition, the economic empowerment program carried out by Lazismu has succeeded in converting zakat recipients into zakat providers by $50 \%$ of the total economic empowerment programs carried out.
\end{abstract}

Keywords: The role of Lazismu, entrepreneurship empowerment programs, zakat recipient

\section{INTRODUCTION}

Zakat institutions have a strategic and decisive role from the dimensions of Islamic teachings and the development of the welfare of the people. In terms of Islamic teachings, zakat is an obligation that must be fulfilled by every Muslim as a form of obligatory worship. In addition to this, the majority of the Indonesian population is Muslim, where in general, Indonesia has great potential in obtaining zakat and developing empowerment programs [1].

In addition to this, zakat institutions have an important role related to the collection and distribution of zakat funds to zakat recipients. In collecting zakat institutions, it is required to create innovative and effective programs to obtain zakat funds from zakat payers considering the enormous potential that cannot be utilized. The latest data in 2019 the potential for zakat in Indonesia reached 233.8 trillion while the new achievement was 6.2 trillion. Meanwhile, the majority of zakat institutions in Indonesia make programs, and the distribution of zakat funds is carried out in the form of consumptive programs instead of economic empowerment programs. Meanwhile, as mandated by the Law on Zakat Number 23 of 2011, the distribution of zakat funds is carried out consumptively and productively to reduce the number of unemployment and poverty in Indonesia, which has not yet been successfully completed [2].
According to a report from the Indonesian National Statistics Agency, the number of unemployed people in February 2020 reached 7.9 million people, while those who worked part-time or only 15 hours per week reached 10.76 million people, while those who were uncertain of working sometimes worked and at certain times did not work reached 9.53 million people so that if you added it up in 2020, the population who need work and have not worked would reach 28.9 million people [3].

In addition, BPS reported that the number of poor people in Indonesia in March 2020 reached 25.14 million people. Based on the place of domicile, it is categorized into two parts, consisting of 39.46 percent of the poor living in urban areas and 60.54 percent in rural areas. The comparison of poverty indicators by place of residence classified by BPS shows a significant difference between the number of poor people living in urban and rural areas where the majority of the poor live in rural areas. Research conducted by Salahuddin El Ayyubi and Henni Eka Saputri in 2020 shows that the majority of zakat institutions make programs, management, and distribution of zakat in the form of consumption. A total of 14.55 percent of the people living in DIY are categorized as low-income families (Badan Pusat Statistik (BPS), 2020)

The management of zakat as regulated in the zakat law number 23 of 2011 states that in the utilization of zakat, it can 
be allocated for productive business activities in the context of handling the poor and improving the economic quality of the people. It was further explained that the distribution of zakat with the model of economic empowerment carried out by zakat institutions could improve the family economy and have great potential to change the status of zakat recipients into zakat givers. This can happen because of the sustainable increase in income obtained from businesses run by zakat recipients [4].

Lazismu is a zakat institution that received the best award from MUI in managing and empowering zakat to improve economic quality through entrepreneurship programs. Lazismu's program was developed in 6 special programs through the Economics Program in the agricultural sector in the form of Tani Bangkit, which was devoted to farmers through a farmer empowerment program with an integrated and environmentally friendly agricultural system. This economic empowerment program for the poor is in collaboration with the Community Empowerment Council (MPM), the central leadership of Muhammadiyah in the form of training, mentoring, and providing fertilizer. Second is the empowerment of farmworkers and fishermen (BRUTAL). The implementation of the empowerment program for workers, farmers, and fishermen is also in collaboration with MPM PP Muhammadiyah, which specifically has the aim of increasing the capacity/economic level of the poor who work as laborers, farmers, and fishermen daily [5].

Another program to improve the economy of the poor was developed by Lazismu Pusat in the form of farmer empowerment with the aim of increasing the quality of livestock prices and having competitiveness. This empowerment is specifically for zakat recipients who are interested and have the will to become entrepreneurs in the form of animal husbandry. This program is also in collaboration with MPM PP Muhammadiyah so that it can run optimally. In addition, Lazismu also developed an economic empowerment program for poor families through the Aisyiyah Family Economic Business Development Program (BUEKA). This program is specifically intended for mothers who receive zakat who are interested in entrepreneurship in order to help improve the family economy.

Lazismu has developed another productive zakat distribution in the form of a program for Micro, Small, and Medium Enterprises (MSMEs) by providing business capital owned by zakat recipients that are already running and strengthening businesses with partnership schemes. Regarding the distribution of empowerment for the poor, they are grouped into four categories: MSMEs in the informal sector for street vendors, Micro MSMEs as zakat recipients who have a business and interest in the craft sector, Dynamic MSMEs as recipients of zakat who carry out entrepreneurial activities by establishing cooperation ( accept sub-contract work) and exports and MSMEs that are already running smoothly with better management (Fast Moving Enterprise) which is ready to transform into a bigger business. This grant is realized for groups with a model of providing business capital and business strengthening with a partnership scheme with a group of 10 people. Another economic empowerment of the poor is realized by Lazismu through the Mualaf empowerment program. This empowerment is specifically for converts to Islam by means of training, mentoring, and capital aimed at improving the family economy [6].

Until now, studies related to the creation, management, and implementation of economic empowerment programs in zakat institutions are still rarely carried out, especially exploring the role of zakat institutions in managing economic empowerment programs through programs that have been run by Lazismu Pusat. The importance of the role of zakat institutions in poverty alleviation through economic empowerment programs is an issue that needs to be raised in a study, so we intend to complete research related to this topic. Explicitly, this study aims to investigate the creation, management, and implementation of the economic empowerment program carried out by Lazismu Pusat, which has been implemented and has succeeded in alleviating poverty[7].

This research is organized into five main parts. The introductory section includes a discussion of the role of zakat institutions in Indonesia and the role of entrepreneurs in poverty alleviation. Section 2 provides an overview of the literature on entrepreneurship programs in zakat institutions and Lazismu. The research method of this paper will be in section 3. An overview of the entrepreneurial empowerment practices that have been carried out by Lazismu as well as explaining the problems and solutions of zakat recipient entrepreneurs, are presented in section 4 , conclusions, and recommendations for further research in section 5 .

\section{LITERATURE REVIEW}

Several studies related to this research, such as by [8], concluded that the management and distribution of zakat need new breakthroughs in order to improve the benefits and quality of zakat institutions for zakat recipients and givers. This is done by distributing zakat through productive economic empowerment programs so that it can help alleviate poverty through economic empowerment of the poor to improve the standard of living of zakat recipients. In addition, the empowerment program can also increase income and, at a later stage, can change the status of zakat recipients into zakat givers. Another study conducted by the 2019 Baznas Strategic Studies Center to evaluate the distribution of productive zakat in the Java and Sumatra regions found that improving the welfare of zakat recipients can be carried out by zakat managers by making distribution programs with an economic empowerment model [2].

Until now, studies on making economic empowerment programs in zakat institutions, especially those related to the creation, management, and realization models of economic empowerment programs at the Central Muhammadiyah Zakat Institutions, are still very rarely carried out. In fact, Lazismu has been considered successful in creating, managing, and realizing an economic empowerment program for the poor recipients of zakat with the zakat model to improve the economy. This is in line with the Zakat Law number 23 of 2011 that in order to alleviate poverty, it is necessary to utilize productive zakat, especially those that have an economic impact with an economic empowerment program model for zakat recipients [9]. 
In line with the concept of zakat in Islam, apart from being obligatory, the purpose of zakat itself is to support and balance the social order in society as stated in (QS. At-Taubah verse 103). [10] revealed that the practice of managing zakat as a support for the economy and independence of the poor has actually been practiced since the time of the Prophet Muhammad and in several Muslim countries until now. Results of Research conducted by [11] The benefits of zakat in the field of economic empowerment only reach $5 \%$ of the benefits of zakat compared to the benefits of all other programs nationally. Research conducted by [12], zakat management through productive economic empowerment program activities can improve the welfare of zakat recipients.

The main factors that support the success of the economic empowerment program are good management and commitment between zakat managers and zakat recipients in running their business. In addition to the commitment from both parties, another supporting factor is the routine guidance carried out by zakat institutions to recipients of economic empowerment programs. Another study conducted by [13] entitled the effect of productive zakat and interest in entrepreneurship on increasing the income of the poor at the Gorontalo City Baznas (2018) concluded that productive zakat and interest in entrepreneurship simultaneously have a positive and significant effect on increasing the income of the poor at Gorontalo city Baznas.

Research conducted by [14] at the Institute of Amil Zakat Yatim Mandiri Surabaya City with a quantitative model concluded that the management of productive zakat has a strong and significant relationship to improving the welfare of mustahik in Surabaya city. Since all previous studies were conducted with a quantitative approach, this study was conducted with a qualitative approach with the aim of complementing and strengthening the previous studies. This study will also provide conclusions related to the creation, management, and realization of economic empowerment programs from two sides, from the point of view of program development, program management, and realization of empowerment programs for zakat recipients in Central Lazismu.

\subsection{Concept and Effectiveness of the Program}

Programming plays a role in determining the future and continuity of an organization, both government and private organizations. The preparation of useful programs does not only apply specifically but can be useful in general. That is, it can be felt by all levels of society or stakeholders. The benefits of programming can be realized after the implementation of a program. The results that have been achieved are seen because, with a structured program, all possibilities to implement or get results as expected will be possible to determine and achieve. The program will also become a reference for an organization's data to carry out activities and become a goal to be achieved. Besides that, the program will become a target of an activity. Thus a program is very important in an organization [15].

If the stages of program preparation can be carried out, then all the activities carried out can be detailed in such a way that in their implementation, there is little possibility to run outside the scope of the program. If this is implemented, it can determine the required budget. The tools desired or used by the people who will implement it, as well as regarding the time and place of a program that has been prepared or determined. To be able to determine what is needed, it is necessary to use resources, as stated by Terry in [16] as follows: "The program can be defined as a comprehensive plan that includes the use of various resources for the future in the form an integrated pattern that establishes a sequence of actions that need to be carried out as well as time schedules for each of these actions in order to achieve the stated goals.

Furthermore,[15] states: "The program is a broad plan that contains the use of different resources for the future in a unified pattern and determines a description of the activities and time plans required by each source, to achieve the stated goals". So what is meant by the program is a broad plan that contains the use of various resources for the future in the form of a pattern that will determine a sequence of activities with time so that the expected goals can be achieved.

Furthermore, [17] states that a program that can be considered good has an innovative element (renewal), the existence of a new initiative approach is indeed developmental in nature, but often a program is more desirable because of the inter-institutional nature of its activities. Programs are also used as problem-solving tools. Meanwhile, (Conchada, \& Edralin, 2017) states that: "Programming is an effort to arrange a series of activities to be carried out, which is also a feature of planning. But program preparation is not planning, because the series of activities that are arranged in program preparation can be carried out not from the initial stage." From the definitions of the experts above, it can be concluded that what is meant by program preparation is a comprehensive plan whose contents contain a plan of activities that must be carried out, what resources must be used and what is needed, by whom will be implemented, and when the plan will be carried out and where the plan will be implemented, all of which are given a serial number of activities according to a predetermined time, this is carried out as an effort to achieve the goals or objectives that have been set.

Furthermore, McDavid \& Hawthorn in [16] defines "programs as meaning relationships that are designed and implemented purposively. A program can be understood as a group of activities intended to achieve one or related objectives. Janiati in Nuraida (2020) defines the program as everything that someone does with the hope that it will bring results or influence. Thus the program can be interpreted as a series of carefully planned activities and, in their implementation, take place in a continuous process, and occur in an organization that involves many people[19].

In this sense, there are four main elements to be categorized as a program, (1), Carefully planned or designed activities. It is not the origin of the design but the activity plan that is prepared with intelligent and careful thinking. (2) The activity takes place continuously from one activity to another. In other words, there is a link between the activities before and after activities. (3) The activity takes place in an organization, both formal and non-formal organizations, not individual activities. (4) The activity in its implementation 
involves many people, not activities carried out by individuals without any relation to the activities of other people. The program is the first element that must exist in order to achieve an activity.

In the program, several aspects are made. In each program, the objectives of the activities to be achieved, the activities taken to achieve the objectives, the rules that must be adhered to and the procedures to be followed, the estimated budget needed, and the implementation strategy must be explained. Through the program, all forms of plans will be more organized and easier to operate. This is in accordance with the understanding of the program described. Thus, what is meant by program preparation is an effort to determine a series of activities to be carried out, including the resources to be used, so that the planned activities achieve the stated goals. Measures of Program Effectiveness From the notion of program effectiveness, it can be concluded that program effectiveness is a way to measure the extent to which the program is running in order to achieve predetermined goals.

\subsection{Program Effectiveness}

The definition of program effectiveness can be formulated as the level of realization of targets that indicate the extent to which program targets have been set [17]. Based on several definitions of effectiveness above, it can be understood that effectiveness is a benchmark to compare the process carried out with the goals and objectives achieved. A program is said to be effective if the efforts or actions taken are in accordance with the expected results. Effectiveness is used as a benchmark to compare the plans and processes carried out with the results achieved.

Aspects of effectiveness based on the opinion of [20], effectiveness can be explained that the effectiveness of a program can be seen from the following aspects: (1) Aspects of the task or function of an institution are said to be effective if they carry out their duties or functions, as well as a learning program will be effective if its duties and functions can be carried out properly and students learn well, (2) Aspects of the plan or program, what is meant by the plan or program here is a programmed learning plan, if all plans can be implemented, then the plan or program is said to be effective; (3) Aspects of provisions and regulations, the effectiveness of a program can also be seen from the functioning or not of the rules that have been made in order to maintain the ongoing process of its activities. This aspect includes rules both related to teachers and related to students. If these rules are implemented properly, it means that the provisions or rules have been effective; and (4) Aspects of goals or ideal conditions, an activity program is said to be effective from the point of view of results if the goals or ideal conditions of the program can be achieved. Assessment of this aspect can be seen from the students' achievements.

According to [21], "program effectiveness is an activity whose implementation shows the accuracy between the desired expectations and the results achieved which are shown by the accuracy of expectations, policies, and results achieved". Program effectiveness is aimed at the correct use of all resources in the context of implementing a program to improve the welfare of society in general, as well as the effectiveness of empowerment programs. According to [22], the effectiveness of the program can be seen as follows: (1) Accuracy of program targets is the extent to which program participants are in line with predetermined targets. (2) Program socialization is the ability of program implementation in conducting program socialization so that information regarding program implementation can be conveyed to the public. (3) The purpose of the program is the ability of respondents to know the purpose of implementing the program. This proves that the socialization carried out regarding the objectives of a program can be understood by the community. (4) Program monitoring is activities carried out during or after the implementation of the program as a form of attention to program participants.

Meanwhile, the measurement of program effectiveness, according to [23], is as follows: (1) Program Understanding, which is to find out how far the community can understand the program. Through the program, all forms of plans will be more organized and easier to operate. By paying attention to the target group, a program can be said to be effective or not. (2) Right on target, which is how the program is designed by the manager for the target group or the extent to which an institution has succeeded in realizing the targets to be achieved. (3) On-time, that is, for the use of time in the implementation of the program, it must be in accordance with a predetermined schedule. With the right time, the program will run effectively. (4) Achieving the goal is to find out whether the objectives of the establishment of the program have been achieved or not. (5) Real Change is to find out how the real change before and after the program. So that it can be measured by the extent to which the program provides an effect or impact as well as real change for the community. Therefore, based on several measures of program effectiveness, it can be concluded that the measure of program effectiveness is a way to measure the extent to which the program is running in order to achieve predetermined goals.

\subsection{Entrepreneurship Theory}

The term entrepreneurship comes from the French entrepreneur, which means intermediary. In the Big Indonesian Dictionary, entrepreneur is defined as "a person who is smart or talented in recognizing new products, determining new production methods, arranging operations for distributors of new products, marketing them and managing operating capital". In terms, entrepreneurship has several meanings from experts. Among them, Jean Babtista in Conner (2016), according to Say entrepreneurship is the (ability) of agents to uniting various means of production and finding the value of their production, so that they are able to bring other people together to build a production organization. In the early 20th century Frank Knight (1921) in Conner linked entrepreneurship to the market. According to him, entrepreneurship is the courage of an entrepreneur in producing and responding to market changes. Another notion of entrepreneurship was proposed by Joseph Schumpeter (1934) in Conner, who defined entrepreneurship as an entrepreneur's innovation as their response to market changes through new combinations. New combinations mean acquiring new raw materials, producing new products, 
finding new production methods, opening up new markets, and implementing new processing management in the industry [24].

According to Pinchot, as quoted by [25], entrepreneurship is the ability to internalize existing talent, engineering, and opportunities, while entrepreneurs are people who dare to take risks, are innovative, creative, never give up, and are able to deal with opportunities appropriately. In accordance with this understanding, Sukardi stated that entrepreneurship is the ability of an entrepreneur to create work for others by establishing, developing, and institutionalizing his own company, ready to take risks and creatively using their potential in developing their production. In the view of the Ministry of National Education, entrepreneurship is an attitude, soul, and ability to create something new, very valuable and useful both for himself and others.

Entrepreneurship is a mental attitude and spirit that is always active and creative, empowered, creates, works, and strives in order to increase income from its business activities. Entrepreneurs are defined as skilled people who take advantage of opportunities in developing their businesses to achieve life achievements. From some of the definitions above, it can be understood that there are various definitions of Entrepreneurship. This is possible because the concept of Entrepreneurship itself is a social science concept that is dynamic, changing along with the development of science and technology. However, in general, it can be concluded that the definition of entrepreneurship is defined as a process that accompanies a business in which the entrepreneur is ready to take all risks, be responsive, creative, and innovative, carry out good management, and think about mutual benefits.

Related to several definitions of Entrepreneurship from experts, Entrepreneurship has several classifications, as follows; (1) Innovating Entrepreneurship is characterized by an aggressive collection of information which is then analyzed and always monitors the results achieved from the process of combining new factors of production. The entrepreneurs in this group generally experiment aggressively and are skilled at practicing the possible transformations attractively; (2) Imitative Entrepreneurship is characterized by a willingness to imitate the innovations successfully implemented by innovative Entrepreneurs; (3) Fabian Entrepreneurship is characterized by a cautious and skeptical attitude, but in the end, still imitating. This causes the emergence of concerns about losing a relative position in the industry and business competition; (4) Drone Entrepreneurship is taken from the equivalent of the word Drone, which is lazy. This entrepreneurship is characterized by a reluctance to carry out changes in production activities, even though this has the consequence of causing losses and lagging other production power; (5) Parasitic Entrepreneurship is grouped as a business in the category of entrepreneurs who always wait for opportunities in adversity to take advantage of certain conditions in order to get as much profit as possible even though it is against the law and ethics. Hoarders, renters are included in this Entrepreneurship classification. The discussion about the concept of Entrepreneurship continues to grow, often with the development of science and existing social dynamics. Other terms appear including, Entrepreneurship and
Entrepreneurial. Entrepreneurship is intended as Entrepreneurship that occurs within the organization as a bridge to the gap between knowledge and market desires. In comparison, Entrepreneurial is an activity in running a business or being an entrepreneur.

Along with the development of the concept of Entrepreneurship, a discussion about the characteristics of Entrepreneurs also emerged. Since the diversity of the concept of Entrepreneurship is put forward by experts, the discussion about the characteristics of Entrepreneurs is also diverse. (Paul Dana, 2017) created seven characters that entrepreneurs must have; (1) Self-confidence, where the indicators are confidence, independence, self-reliance, and optimism; (2) Task and result-oriented. Indications of this are the need for achievement, profit-oriented, have perseverance and fortitude, have strong determination, like to work hard, are energetic and have initiative; (3) Risk-taker. The indication is the ability to take risks and prefer challenges; (4); Leadership. In this case, it is indicated by behaving like a leader, being able to get along with others, and liking constructive suggestions and criticism; (5) Originality The signs are high innovation and creativity, flexibility, versatility, and a vast business network; (6) Future-oriented. The indication is to have a perception and a way of looking ahead; (7) Honest and Diligent. This is characterized by the belief that life is the same as work.

McClelland, as quoted by [27], made the concept of Need For Achievement by detailing the characteristics of Entrepreneurs as follows; (1) Prefers work with realistic risks; (2) Work harder in tasks that require mental ability; (3) Not working harder solely because of monetary rewards; (4) Desire to work in situations where personal achievement can be obtained; (5) Demonstrate better performance under conditions that provide clearly positive feedback; (6) Tend to think into the future and have a long-term plan.

Meanwhile, Bygrave also suggested several characteristics of entrepreneurs, including; (1) Dream, that is, an entrepreneur has a vision of how he wants the future from his personal life and business development, including the ability to realize his desires; (2) Decisiveness, an entrepreneur is a person who works quickly and is responsive and precise in making decisions with full calculation; (3) Doers, quickly follow up on decisions that have been taken by maximizing existing opportunities; (4) Determination, have accuracy and a high sense of responsibility, and do not give up easily;(5) Dedication, has a high dedication to his business; (6) Love the business and its business; (7) Details, have high accuracy, and never underestimate the slightest cause of business failure; (8) Destiny, responsible for the goals to be achieved and not dependent on others, and free (8) Dollars of money is one measure of success; (9) Distribute, willing to distribute his business ownership to people who can be trusted, critical, and willing to be invited to succeed together.

The characteristics possessed by an entrepreneur are not something that comes suddenly but are produced from certain processes through the factors that deliver them. Some of those factors are; (1) Environmental Factors. According to Duchesneau, most successful entrepreneurs are people who were raised by parents who were also entrepreneurs because of the many experiences they have. Likewise, the influence of 
parents' work on the growth of their children's entrepreneurial spirit is very significant; (2) Education Factors. A good education will provide better knowledge in managing their business. It will be very helpful in overcoming the problem of correcting irregularities in the business; (3) Age Factor. According to Staw, age can have a correlation with the level of success if it is associated with the length of time a person has been an entrepreneur. In other words, the older an entrepreneur gets, the more experience he has in his business; (4) Work Experience Factor. Work experience is a driving factor for the success of an entrepreneur, the experience of dissatisfaction and failure has also become one of the motivations in developing a new business.

Therefore, entrepreneurship is an essential factor in economic development. Entrepreneurship also determines the success of the economic activities carried out. Therefore, entrepreneurship is also associated with the term religion, which is the main motivator by the Muslim community, including in Indonesia. For this reason, so that the Islamic spirit about entrepreneurship can be better understood, it is necessary to continue to conduct studies and development practices, especially in zakat institutions.

\section{METHODOLOGY}

This study used a qualitative method research design with a case study strategy (Figure 2) model (Yin, 2018) The case study research was carried out to find out a decision or a series of activities: why it was taken, how it was carried out, and with what results. The main focus of case studies, in general, includes individuals, organizations, processes, programs, environments, institutions, and events. This study aimed to explore more deeply the activities carried out by the object of research in the field directly.

In addition, this method is designed to be a medium for finding something new that cannot be found when using a questionnaire or survey model. This research was located in Central Lazismu. Referring to the Central Lazismu data, the creation of productive economic empowerment programs has been being carried out since 2015 , which has been carried out in several Lazismu areas throughout Indonesia.

Furthermore, for technical data collection, interviews were carried out with the director of Lazismu, the head of the economic empowerment program manager, and the recipients of the productive economic empowerment program that was already running, in this case, the recipients of the zakat entrepreneurship program from Lazismu. Furthermore, interviews with recipients of the empowerment program were conveyed to the recipients of the business empowerment program, in this case, the mustahik recipients of venture capital funds that have been running for one year. Furthermore, this form of data collection was carried out in the form of semi-structured interviews and questionnaires. In more detail, the formulation of the methodology in this study was described in the method below:

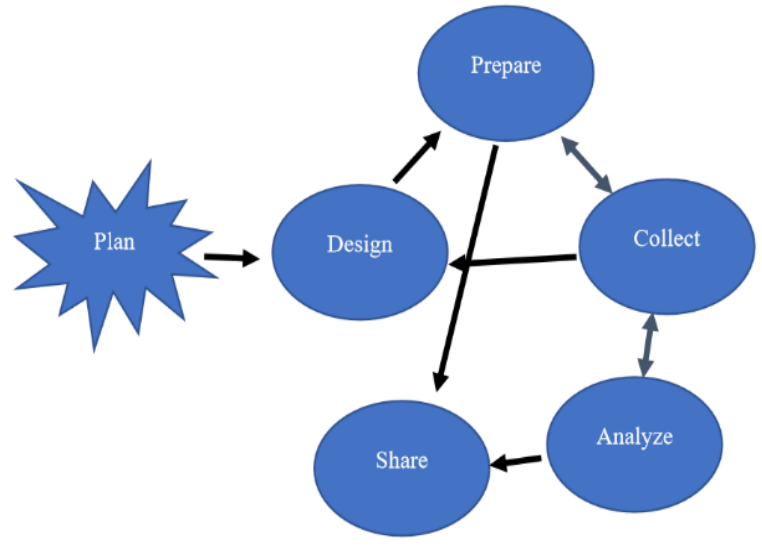

Robert K. Yin Case Study (2018.p.32

Figure 1. Qualitative research method with case study model by Yin (2018).

1. Plan (Doing research planning): carried out to estimate the time, cost, and suitability of the research topic.

2. Design (Creating a research design): determine the model and steps to be carried out in the research.

3. Prepare: prepare instruments and other equipment according to research needs. At the same time, validation tests are carried out to competent parties (share).

4. Collect (collection of data): collect data according to the research plan as well as design a collection model.

5. Analyze (perform data analysis: the steps taken are data reduction, data display, and conclusions.

6. Share (make a research report)

\section{RESULT AND ANALYSIS}

Several theories about programming state that before developing an effective work program, according to Brian Tracy, it is necessary to arrange steps in making an effective and impactful work program. Some of these things are, clearly define goals, write and measure goals, determine deadlines, list all actions that can be taken to achieve goals and combine the 4 steps that have been arranged in a work program. Regarding the effective steps in making the Lazismu work program, the results of an interview with the President Director of Lazismu Mr. Sabeth Abi Lowo revealed that effective steps have been taken in making the program according to the criteria described by Brian Tracy above. However, there is no complete combination related to the steps that have been arranged in a work program that is connected between one program and another [29].

On the other hand, Lazismu uses the principle of mutual deliberation in the form of a meeting one year prior to the realization of the program. Programming specifically analyzes and predicts current conditions. In that case, the economic empowerment program carried out is to identify the economic constraints that will be faced by the poor in the coming year. Furthermore, the program is made based on priorities that become the reference for program targets in 
accordance with the pillars that have been determined by Lazismu. The six pillars include the pillars of education, health, da'wah, social, humanitarian and economic. In particular, the economic sector is divided into programs that target recipients in the economic sectors of the zakat recipient community.

The economic pillars currently being developed by Lazismu are agriculture, plantations, fishermen, animal husbandry, micro, small and medium enterprises (MSMEs), and micro businesses that are carried out on a non-permanent basis (pedestrians) through the provision of business capital assistance. Giving capital to zakat recipients is based on the business being run, farmers are given six months, traders five times a week (6-7 days). The program for providing community economic empowerment funds based on the program made by Lazismu is $70 \%$ while the remaining $30 \%$ is distributed based on proposals submitted by the community who will run their program and business activities. After careful scrutiny, the programs that issue large funds are programs that are in collaboration with third parties who provide funds for the implementation of certain programs that must be carried out.

Table 1. Central Lazismu entrepreneurship empowerment program.

\begin{tabular}{|l|l|l|l|}
\hline No & Program Name & $\begin{array}{l}\text { Number of } \\
\text { Participant }\end{array}$ & $\begin{array}{l}\text { Business } \\
\text { success } \\
\text { average }\end{array}$ \\
\hline 1 & Tani Bangkit & 175 & \multirow{2}{*}{$50 \%$} \\
\hline 2 & MSMEs & 136 & \multirow{2}{*}{50} \\
\hline 3 & Farm & 80 & \\
\hline 4 & Business Training & 200 & \\
\hline 5 & Islamic micro-institutions & 1 & \\
\hline
\end{tabular}

Source: Primary Data 2021 (processed)

The table above can be explained that the number of recipients of the Lazismu economic empowerment program for the period June - December 2021 include 175 farmers, 136 SMEs, 80 recipients of farms, 200 batik making training and 1 microfinance institution (BMT) that received capital assistance from Lazismu. Furthermore, for the food security program as many as 6600 beneficiaries, although in general it can be categorized as supporting the economic program, but it is more consumptive so that it is not classified as a productive economic empowerment program. After observing the number of recipients of the food security program, because during this pandemic, more people need assistance in the context of restoring general economic conditions due to the large number of people who do not have jobs or are dismissed from their workplaces due to the Covid19 outbreak. The realization of the economic empowerment program for the months of June - December 2021 is 2.6 billion rupiah. If it is specifically specified for the productive economic empowerment program as many as 592 people in a 6-month period, namely June to December 2021. In detail it can be explained that during that period Lazsimu has succeeded in alleviating poverty and changing the status of mustahik to muzaki as many as 296 people. If the distribution activity can be carried out for 1 year, it will produce at least 592 new entrepreneurs.
The evaluation stage of the ongoing economic empowerment program, especially for small and mediumsized enterprises, is carried out to provide an assessment of the feasibility of the business being carried out related to the provision of further capital. The results of the analysis serve as a reference for Lazismu whether or not to provide capital assistance. This is done so that business continuity is maintained. For business actors who have succeeded in increasing their income and can independently continue their business, there is no need for assistance. Furthermore, for entrepreneurs who fail to run their business and are no longer able to continue, no assistance will be given. Meanwhile, for business actors who experience a decline in their business but are still enthusiastic about running a business and calculatingly the business can run and survive and even increase after being given assistance, priority is given to business capital assistance [30].

Regarding the risk analysis of the business being carried out, in principle, Lazismu has conducted an analysis of the risks that arise when running a business. Although the analysis carried out has not fully implemented the risk management standards that have been set by BAZNAS in order to minimize the risks that will occur. However, the application of risk management plays a role as a determinant of the realization of business empowerment capital assistance. The application of other forms of evaluation is carried out by Lazismu external parties in order to improve the performance and success of the programs run by the central Lazismu.

Lazismu's success in fostering the spirit of entrepreneurship by creating entrepreneurial empowerment programs for the poor in general can be said to be achieved by the success of fostering business actors through established programs. Furthermore, it can summaries that Lazismu are successful in cultivating an entrepreneurial spirit as described by McClelland cited by Yuyus Suryana and Kartib Bayu by comparing the concept of an entrepreneur who prefers work despite the risks, working harder is not only for money, always want to work for self-actualization, perform better and think in the future. This success can be seen in the entrepreneurs who have been successfully fostered by Lazismu and have proven successful in advancing their business.

Programming when viewed from the SMART model which was coined by George T Doran in 1981 that the program must be made based on specific, measurable, achievable, relevant, time-based criteria. Furthermore, the program that has been made by Lazismu has met the special criteria, the measuring instrument has been determined so that it can be measured and can be achieved if it follows the specified criteria. In addition, the program made is also relevant to the conditions and needs of program recipients and the conditions of economic problems because the program is made based on current and future economic analysis and predictions. Meanwhile, related to the target time, Lazismu has also made an implementation schedule until the program has been completed. Thus, the programming implemented by Lazismu meets the requirements as set out in the smart goals theory. 


\section{CONCLUSION}

Lazismu's role through the poor community empowerment program is carried out in several stages, starting from the preparation of the strategic plan before the program is implemented, determining the type of program, implementation, evaluation and mentoring. Meanwhile, the management and implementation model Lazismu creates a special team and collaborates with others professional team in order to make the program implementation a success. The program of Lazismu is in the form of rising farmers, MSMEs, livestock, capital assistance for Islamic microfinance institutions in accordance with the theory of raising the spirit of entrepreneurship and smart goals. Overall economic empowerment program carried out by Lazismu, in general, it went well and smoothly according to the planned target. In addition, the economic empowerment program carried out by Lazismu has succeeded in converting zakat recipients into zakat providers by $50 \%$ of the total economic empowerment programs carried out.

\section{REFERENCES}

[1] J. A. Hafidhuddin, D, Membangun Peradaban Zakat Meniti Jalan Kegemilangan Zakat. 2006.

[2] Puskas Baznas, Zakat Outlook 2019. 2018.

[3] Badan Pusat Statistik (BPS), "Data Sosial Ekonomi," 2019.

[4] A. W. Triatmo, R. Karsidi, D. T. Kartono, and S. Suwarto, "The Inefficiency of Zakat Management in BAZNAS Sragen Indonesia," Afkaruna Indones. Interdiscip. J. Islam. Stud., vol. 20, no. 2, 2, pp. 2020. https://doi.org/10.18196/AIIJIS.2020.0121.209-227

[5] S. Shobron and T. Masruhan, "Pengembangan Ekonomi Produktif Di Lazismu Kabupaten Demak Jawa Tengah Tahun 2017," Profetika, vol. 18, no. 1, pp. 55-63, 2017.

[6] Lazismu, "Lazismu Entrepreneurship Programs," Lazismu, 2019. [Online]. Available: https://www.lazismu.org

[7] Nurjamal, "Lazismu Terima Penghargaan Lembaga Filantropi Peduli Ekonomi Umat dari MUI," gomuslim.co.id, 2019. [Online]. Available: https://www.gomuslim.co.id/read/news/2019/03/27/11268/p-lazismu-terima-penghargaan-lembaga-filantropi-peduliekonomi-umat-dari-mui-p-.html.

[8] Warto, "Zakat produktif sebagai penggerak ekonomi rakyat," J. Tafsir Hadits, vol. 1, no. December, 2018.

[9] K. Kinanti, M. H. Zaenal, and K. Kinanti, "The Role of Zakat to Strengthen The Rural Mustahiq Community Based on Entrepreneurship," Puskas Work. Pap. Ser., no. January, pp. $1-14,2018$

[10] A. Saleh and P. Muljono, "The Empowerment Sustainable of Micro and Small Entrepreneurs in the Implementation of Corporate Social Responsibility in Bogor District West Java Faculity of Agriculture Nusa Bangsa University," Int. J. Sci. Eng. Home, vol. 4, no. 9, pp. 138-147, 2014.

[11] Puskas BAZNAS RI, Indikator Pemetaan Potensi Zakat ( IPPZ ). Jakarta: Puskas Baznas, 2019.

[12] S. Tazkia, "Examining the Efficiency of Zakat Management: Indonesian Zakat Institutions Experiences," vol. 3, no. 1, pp. 37-55, 2018.

[13] A. Mardiana and A. Y. Lihawa, "Pengaruh Zakat Produktif dan Minat Berwirausaha Terhadap Peningkatan Pendapatan Masyarakat Miskin Pada BAZNAS Kota Gorontalo," Li Falah J. Stud. Ekon. dan Bisnis Islam, vol. 3, no. 1, pp. 18-36, 2018. http://dx.doi.org/10.31332/lifalah.v3i1.1185
[14] R. Hidajat, "Penerapan Manajemen Zakat Produktif Dalam Meningkatkan Ekonomi Umat Di Pkpu (Pos Keadilan Peduli Umat) Kota Makassar," Millah J. Stud. Agama, vol. 1, no. 1, pp. 63-84, 2017. https://doi.org/10.20885/millah.vol17.iss1.art4

[15] U. G. Mada, "Zakat Based on Programs ' Tender: Effectiveness of Productive Zakat Fundraising in Indonesia," 2018.

[16] N. Nuraida, "Efektifitas Pelaksanaan Program Keluarga Harapan (PKH) di Kecamatan Cisalak Kabupaten Subang," World Public Adm. J., vol. 1, no. 2, pp. 148-165, 2020. https://doi.org/10.37950/wpaj.v1i2.741

[17] N. W. Budiani, "Efektivitas Program Penanggulangan Pengangguran Karang Taruna 'Eka Taruna Bhakti' Desa Sumerta Kelod Kecamatan Denpasar Timur Kota Denpasar," J. Ekon. dan Sos., vol. 2, no. 1, pp. 49-57, 2017.

[18] M. I. P. Conchada, M. M. Tiongco, P. J. Castillo, and D. E. Edralin, "Evaluating government programs for enhancing the welfare of the youth towards entrepreneurship," DLSU Bus. Econ. Rev., vol. 27, no. 1, pp. 59-71, 2017.

[19] H. Muhammad, D. Lubis, and D. B. Hakim, "Faktor-faktor yang Memengaruhi Keberhasilan Usaha Mustahik pada Program Zakat Produktif di LAZ An-Nuur," Al-Muzara'ah, vol. 6, no. 1, pp. 1-14, 2018.

[20] Georgopolous, Efektivitas Organisasi. Jakarta: Erlangga, 1995.

[21] Makmur, Efektivitas Kebijakan Kelembagaan Pengawasan. Bandung, Indonesia: Refliks Aditama, 2011.

[22] Mahmudi, Efektivitas Organisasi. Edisi Kedua. Yogyakarta: Penerbit STIM YKPN, Yogyakarta., 2010.

[23] E. Sutrisno, Manajemen Sumber Daya Manusia. Jakarta Pusat: Prenada Media Group, 2011.

[24] D. F. K. Howvard Frederick, Allan O' Conner, Entrepreneurship, 4th ed. Melbourne: Cengage Learning Australia, 2016.

[25] S. A. Zahra and M. Wright, "Understanding the Social Role of Entrepreneurship," J. Manag. Stud., no. 33, p. n/a-n/a, 2015.

[26] and S. G.-R. Vanessa Ratten, Veland Ramadani, Le 'o-Paul Dana, "Islamic Entrepreneurship and Management: Culture, Religion and Society," in Entrepreneurship and Management in an Islamic Context, Switzerland: Springer, 2017, p. 7.

[27] D. F. Kuratko, J. S. Hornsby, and J. Hayton, "Corporate entrepreneurship: the innovative challenge for a new global economic reality," Small Bus. Econ., vol. 45, no. 2, pp. 245253, 2015.

[28] Robert K. Yin, Case Study Research and Applications: Design and Methods, Sixth Edit. California: SAGE Publications Ltd, 2018.

[29] Interview with Directur of Lazismu Pusat " Sabeth Abilowo" $16^{\text {th }}-7^{\text {th }}$ July 2021 Jakarta.

[30] Interview With Manager of Entrepreneurship Program Lazoismu," Falhan" $16^{\text {th }}$ August 2021 Jakarta. 